\title{
O MiNimalismo PENAL DE RAÚl ZAFFARONi E UM Diálogo COM A HERMENÊUTICA FILOSÓFICA COMO CAMINHOS PARA UMA RECONSTRUÇÃO DO SISTEMA PENAL BRASILEIRO
}

\author{
THE CRIMINAL MINIMALISM OF RAÚL ZAFFARONI AND A DIALOGUE WITH \\ PHILOSOPHICAL HERMENEUTICS AS WAYS FOR A RECONSTRUCTION OF \\ THE BRAZILIAN CRIMINAL JUSTICE SYSTEM
}

\author{
Edson Vieira da Silva Filho \\ Matheus Maciel Paiva ${ }^{2}$
}

\section{RESUMO}

O presente artigo tem como proposta elucidar os principais aspectos do pensamento de Raúl Zaffaroni no que concerne precisamente ao seu modelo teórico de sistema criminal que, por sua vez, se enquadra no denominado minimalismo penal. No mesmo sentido, demonstrar a proximidade entre a proposta de Zaffaroni e o constitucionalismo brasileiro vigente, especificamente sob a perspectiva da hermenêutica filosófica. O método utilizado no geral é o analítico-descritivo, valendo-se de dados estatísticos para descrição da realidade políticocriminal brasileira; além disso, deve-se ter em mente a fenomenologia presente principalmente nas etapas finais do artigo. Dois pontos nevrálgicos do pensamento do presente autor são o realismo marginal e o colonialismo/neocolonialismo; partindo basicamente destes dois elementos conclui-se a possibilidade de realizar um resgate da facticidade, da historicidade própria da realidade latino-americana, aspecto que converge com a proposta hermenêutica de bases fenomenológicas existencialistas, isto é, que tem como solo o arcabouço fillosófico da analítica existencial ou ontologia fundamental. Por sua vez, compreende-se que a utilização da hermenêutica filosófica para compreensão e interpretação do texto constitucional é um caminho

\footnotetext{
${ }^{1}$ Pós Doutor pela UNISINOS, sob a orientação do Professor Doutor Lenio Luiz Streck; Doutor em Direito pela UNESA (2012 - conceito 5 CAPES) na linha Direitos Fundamentais e Novos Direitos com nota 9,5 por unanimidade da banca, Mestre pela Universidade Federal do Paraná (2006 - conceito 6 CAPES), com conceito "A" e nota 10 por unanimidade da banca . Mestre pela Universidade São Francisco (2002), Graduado em Direito pela PUC Belos Horizonte -MG (1986). Delegado de Polícia Classe Geral, aposentado - Polícia Civil do Estado de Minas Gerais. Gestor do Núcleo de Atividades Complementares da Faculdade de Direito do Sul de Minas, Professor Adjunto da Faculdade de Direito do Sul de Minas em tempo integral (DE) e membro do Núcleo Docente Estruturante. Professor do PPGD da FDSM. Vice Presidente da Fundação Sul Mineira de Ensino. Tem experiência na área de Direito, com ênfase em Direitos Fundamentais e garantias penais, atuando principalmente no seguinte tema: a (i)legitimidade do direito penal no Brasil contemporâneo frente ao paradigma do Estado Democrático de Direitos. Faculdade de Direito do Sul de Minas (FDSM). Minas Gerais. Lattes: http://lattes.cnpq. br/222528900235509 ORCID:https://orcid.org/ 0000-0002-3997-641X E-mail:evsilvaf@globo.com

${ }^{2}$ Mestrando na área de Filosofia, linha de pesquisa Ética e Política, na Universidade Federal do Paraná. Bolsista CAPES/DS. Graduado em Direito pela Faculdade de Direito do Sul de Minas, no ano de 2019. Participou do programa de Iniciação Científica pela FAPEMIG nos anos de 2017 e 2018. Realizou estágio em escritório de advocacia nos anos de 2015 e 2016, bem como no Ministério Público Estadual da Comarca de Paraisópolis/MG em 2019. Realizou pesquisas na área de Criminologia e Sociologia no ano de 2017; e em 2018 concentrada na área de Filosofia Política. Participa de grupo de pesquisa "Razão Crítica e Justiça Penal" desde 2017; grupo de pesquisa "Democracia em Crise: violência biopolítica e gestão neoliberal da vida de populações". Além disso, atuou como monitor na disciplina de Sociedade e Criminalidade e também Sociologia e Antropologia nos anos de 2018 e 2019.Universidade Federal do Paraná (UFPR). Paraná. Lattes: http://lattes.cnpq.br/6856280513931401 ORCID: http://orcid.org/0000-0003-1932-2387 E-mail: matheusmacielpaivacxb@gmail.com
} 
adequado para sanar a ruptura paradigmática atual, bem como reconstruir adequadamente um sistema criminal.

Palavras-chave: colonialismo; criminologia; fenomenologia; hermenêutica; minimalismo.

\begin{abstract}
The proposal of this paper is to clarify the main aspects of Raúl Zaffaroni's thought about his theoretical model of the criminal justice system, which fits a criminal minimalism. In the same way, it's to demonstrate a close study between the proposal of Zaffaroni and the current Brazilian constitutionalism, particularly under the perspective on hermeneutics. In general, it uses descriptive and analytical methods with statistical data to describe the reality of the criminal policy in Brazil. Moreover, it is necessary to keep in mind the phenomenology present in the final stages of this paper. The most important aspects of the author's idea are the realism of marginalism and the colonialism/neocolonialism. As a result of these two elements there is a possibility of achieving the rescue of the facticity and the history of Latin America's reality. This aspect converges with the proposal of hermeneutics with existential phenomenology, that is to say, it has as a base the philosophy of existential analysis or fundamental ontology. Therefore, it is concluded that the use of hermeneutics to understand and interpret the constitutional text is an appropriate way to correct the current paradigm shift, as well as reconstructing the criminal justice system properly.
\end{abstract}

Keywords: colonialismo; criminology; hermeneutic; minimalism; phenomenology.

\title{
1. CONSIDERAÇÕES INICIAIS
}

No campo do estudo criminológico contemporâneo destacam-se ao menos três movimentos epistemológicos que pretendem, através de seus respectivos arcabouços argumentativos, desenvolver e sustentar determinado modelo punitivo que o ente estatal deve implementar e atuar; sendo, portanto, o mais adequado à realidade econômico-social no que concerne à capacidade de resolução e redução dos conflitos delituosos do quadro social específico. Dito em outros termos, há por um lado o modelo maximalista penal, sustentando o clamor por um direito penal forte, intolerante a qualquer conduta minimamente marginal, tendo como referência ideais ainda modernos. De outro ponto o abolicionismo penal, que em realidade não pode ser considerado um "modelo" de sistema punitivo uma vez que pugna pela extinção deste, e o fomento a alternativas administrativas e interindividuais para resolução dos conflitos. Por fim, o modelo punitivo mínimo de construção e atuação do sistema penal. O foco do presente artigo é examinar o pensamento minimalista de Raúl Zaffaroni, fazendo um paralelo com a hermenêutica filosófica de premissas fenomenológicas. 
Parte-se, portanto, do pressuposto de que tanto o maximalismo penal, especificamente as políticas de tolerância zero; quanto o abolicionismo penal, precisamente o de Hulsman, não são propostas e caminhos adequados para a estruturação - ou, no caso deste último, desarticulação - de um sistema penal ideal - não no sentido utópico ou puramente perfeito - à realidade brasileira. É neste âmbito, de certa forma vago, que os modelos minimalistas ganham fôlego e se desenvolvem a partir da segunda metade do século XX, harmonizando com os crescentes debates em torno dos direitos humanos e a necessidade, após os acontecimentos da $2^{\text {a }}$ Guerra Mundial, de um resgate e uma releitura global de suas estruturas, com o intuito de fortalecer seus vínculos nos ordenamentos jurídicos internos dos países, bem como o desenvolvimento de agentes internacionais públicos e privados para a concretização, a partir de diversas dinâmicas, destes direitos como um norte adequado à toda humanidade.

$\mathrm{O}$ minimalismo penal apresenta autores que o constituem por caminhos diferentes. O objetivo deste artigo não é destrinchar essa variedade de paradigmas epistemológicos que, apesar de interessante, estenderia por demais o trabalho, nos distanciando do telos pretendido que, em suma, é a busca por um modelo teórico penal que permita construir um sistema punitivo adequado à nossa realidade sócio-política e, inevitavelmente, constitucional. Pode-se dizer, assim, que o marco teórico deste empreendimento e, consequentemente, para a abordagem do minimalismo, será Raúl Zaffaroni, uma vez que, como se verá mais à frente, ele busca desenvolver uma teoria específica para a realidade latino-americana.

De qualquer maneira vale abordar suscintamente, para pôr em tela as suas peculiaridades, alguns autores e os pontos iniciais de suas construções ao minimalismo penal. Dentre eles encontra-se Alessandro Baratta que em seu livro Criminologia Crítica e Crítica do Direito Penal, precisamente no capítulo XV, desenvolve a Política Criminal Alternativa ${ }^{3}$, uma proposta que objetiva uma reforma sócio-política, institucional que, em suma, está focada na realidade de classes subalternas - vulneráveis - aliviando as pressões negativas do sistema punitivo sobre estas. Alguns aspectos centrais são: uma análise materialista do sistema de produção; desenvolver mecanismos eficientes para combater a criminalidade econômica; "contração", redução, enxugamento do sistema penal, como a descriminalização de certas condutas; substituição de sanções penais para formas menos violentas de estigmatização;

\footnotetext{
${ }^{3}$ Baratta faz uma importante distinção, que o permite progredir na sua proposta, entre política penal como o "âmbito do exercício da função punitiva do Estado"; e política criminal com caráter de "transformação social e institucional", para além de apenas um instrumento punitivo, pretende-se que estas políticas atuem não, ou apenas e principalmente, na criminalidade, no desvio, nos comportamentos negativos, mas sim nos problemas estruturais do sistema de produção e das instituições estatais como um todo, portanto, tem um caráter reformista e, em certo sentido, materialista ao afirmar a transformação a partir da "superação das relações sociais de produção capitalistas". (BARATTA, 2011, p. 201).
} 
reforma e extinção da instituição-prisão na forma como está posta; desenvolver uma "consciência alternativa" a partir de uma adequação da opinião pública e dos processos ideológicos, buscando reverter a relação de hegemonia entre as classes sociais (BARATTA, 2011, p. 201).

Outro autor que realiza vastas contribuições à criminologia e outras áreas do saber é Luigi Ferrajoli que em seu livro Direito e Razão: A Teoria do Garantismo Penal, desenvolve seu pensamento e as estruturas de seu modelo penal minimalista, especificamente na quinta parte desta obra. Importante ressaltar que este autor, na construção de seu arcabouço teórico, possui um caráter multidisciplinar forte, trabalhando muitas vezes desde de uma filosofia política, uma fenomenologia, até uma dogmática do direito mais própria. O minimalismo de Ferrajoli parte da teoria do Garantismo ${ }^{4}$ que, na verdade, pode e deve ser utilizada para trabalhar o direito como um todo e, consequentemente, o penal. Trata-se de uma teoria extremamente vinculada às noções de direitos fundamentais - tratando as garantias liberais ou negativas e, por outro lado, garantias sociais ou positivas -, paradigmas de Estado moderno, ou seja, o Liberal, o Social e o Democrático, bem como sistemas democráticos - como a democracia formal e a democracia substancial (FERRAJOLI, 2002, p. 691/694). Em suma, pode-se dizer ser um caminho mais amplo de análise e crítica, a partir do qual o minimalismo surgiria como uma opção a ser concretizada para sanar a crise do sistema punitivo, as antinomias por ele produzidas, a ineficiência da Constituição da República, seus princípios garantidores e o distanciamento entre o sistema e a realidade.

Estes são apenas alguns autores que trabalham o tema e, apesar de construírem caminhos diferentes e próprios, são harmonizáveis de um modo geral, assim como Zaffaroni, como se verá nos próximos itens. Todos assinalam uma deslegitimação do sistema punitivo, problemas estruturais que não podem ser sanados apenas com uma simples reforma, isto é, um novo código penal ou processual penal. É preciso a construção de um novo sistema, completamente reorganizado e capaz de pôr em prática as previsões constitucionais. Neste sentido, Zaffaroni permitirá pensar um modelo adequado à nossa realidade político-social.

\footnotetext{
${ }^{4}$ Garantismo remeterá à três conceitos/significados distintos, mas conexos: a) a ideia de um modelo normativo de direito, recaindo estritamente sobre o corpo normativo e seu nível de garantismo, de princípios fundamentais e instrumentos para sua consecução; b) uma teoria jurídica ou teoria da divergência, separando o "ser" do "dever ser", entre o texto constitucional e sua execução prática, ou seja, o grau de efetividade; c) por fim, uma filosofia política, de separação do ponto de vista externo (ético-político) e interno (jurídico), sua necessária análise e os problemas derivados de uma crise entre estes polos. (FERRAJOLI, 2002. p. 684/686).
} 


\section{O MAXIMALISMO PENAL E A DOUTRINA DA TOLERÂNCIA ZERO}

A ascensão do maximalismo penal ocorre na modernidade, portanto o surgimento de certos elementos dessa nova sociedade burguesa, que se desenvolve na transição entre a Idade Média e o novo paradigma moderno, que se deu no início do século XVIII e percorreu todo o século XIX (FOUCAULT, 2014a, p. 12), foram responsáveis pelo clamor social ao direito penal forte. E serão estes os elementos abordados neste item. Em suma, buscou-se adequar o modelo punitivo ao novo discurso racionalista, libertário, igualitário e fraterno que este contexto sóciopolítico exigia, ou seja, foi preciso buscar uma nova economia punitiva capaz de dialogar harmonicamente com os pressupostos e ideais modernos.

Na verdade, a passagem de uma criminalidade de sangue para uma criminalidade de fraude faz parte de todo um mecanismo complexo, onde figuram o desenvolvimento da produção, o aumento das riquezas, uma valorização jurídica e moral maior das relações de propriedade, métodos de vigilância mais rigorosos, um policiamento mais estreito da população, técnicas mais bem ajustadas de descoberta, de captura, de informação. (FOUCAULT, 2014a, p. 98)

O primeiro elemento a ser trabalhado é o desenvolvimento da sociedade burguesa/capitalista, responsável por fomentar a industrialização e, consequentemente, a valorização da propriedade, tendo como ponto de discussão a necessidade de mão-de-obra que, agora, não é mais composta por servos, mas que ainda deve ser servil para sua manutenção. Como se verá, todo este arranjo social, em última análise, desagua na sociedade complexa e também numa sociedade de risco (BECK, 2010, p. 18), que atinge a dinâmica do sistema punitivo, assim como na forma de aplicação da punição. Contudo, trata-se de um processo gradativo, que se inicia em meados do século XVIII, principalmente com o advento da Revolução Industrial (CIRINO, 2006, p. 66).

Ocorre que, com a ascensão de uma nova classe dominante, a burguesa, mais precisamente os comerciantes e industriais, o discurso jurídico-penal transformou-se de maneira a reproduzir este status quo, mantendo a hegemonia econômica e política recém construída nas mãos desta classe. Para isso, a dinâmica do sistema punitivo agirá de forma seletiva (ZAFFARONI, 2014, p. 43). Destaca-se que este novo arranjo social dará origem à concentração populacional nas cidades, provocando uma urbanização, e o consequente surgimento de uma periferia e marginalização social crescente, produzindo assim os indesejáveis (ZAFFARONI, 2014, p. 44), que serão a clientela preferencial de atuação do poder punitivo. É relevante considerar também que a Revolução Industrial altera a própria dinâmica 
dos meios de produção, devido à introdução de máquinas, o que estreita a relação entre produção/mão-de-obra (CIRINO, 2006, p. 67).

Os aspectos supramencionados são importantes por estarem diretamente vinculados à nova economia punitiva que o Estado Moderno exercerá, acrescentando nisso a própria busca pela segurança jurídico-penal que mais a frente será abordada. Esse novo arranjo econômico das relações sociais de produção capitalista irá marginalizar certos grupos sociais, sendo aqueles sujeitos excluídos do mercado de trabalho, definidos como força de trabalho excedente (CIRINO, 2012, p. 18). Há nisso uma nova forma de interpretação do homem, que se tornará instrumento para produção, um "homem-máquina", uma redução materialista da alma, focada na docilidade e utilidade dos corpos (FOUCAULT, 2014a, p. 135).

Será este "exército industrial da reserva" (CIRINO, 2006, p. 66) uma das variáveis importantes na criminalidade. Pressupõe-se que com o aumento do desemprego há também o da criminalidade e, portanto, do índice de encarceramento e punição. Contudo há um terceira e intermediária variável que é a própria criminalidade responsável por tornar essa dinâmica mais complexa e sustentar a crítica ao novo modelo punitivo. Observa-se que, na verdade, o índice de punição e encarceramento pode aumentar mesmo reduzindo a criminalidade e vice-versa, exatamente pelo fato do mercado de trabalho influenciar diretamente nesta sistemática (CIRINO, 2006, p. 70/71).

Percebe-se que a nova forma de punição, o encarceramento, está diretamente vinculada à produção de mão-de-obra, tendo como objetivo a docilização dos corpos (FOUCAULT, 2014a, p. 28). Mas além disso, tendo como princípio uma dosimetria do tempo de privação da liberdade do delinquente, a prisão afeta diretamente a inserção e presença do sujeito no próprio mercado de trabalho (CIRINO, 2006, p. 67). Ou seja, o caráter punitivo dessa nova economia do poder atinge não só a liberdade, como também a propriedade e o corpo do sujeito. Há, em síntese, a substituição do crime - enquanto objeto de julgamento - para o homem, a fim de realizar um controle social através de uma rede microfísica, capilar de poder.

Todo o processo acima exposto acarretará o surgimento, ou criação, dos "Indesejáveis" ou também inimigos da sociedade, sendo este o segundo elemento que corrobora ao clamor de um direito penal forte. Partindo da teoria contratualista - de uma convergência de vontades individuais para a consecução de um instrumento racional capaz de sustentar um Estado Civil, ou seja, um contrato - todo sujeito que comete um ato contrário ao bem-estar dessa sociedade, e que paradoxalmente a compõe, deve ser tratado como inimigo e punido. Na verdade, desta forma, este sujeito torna-se um traidor comum que tem contra si toda a sociedade, legitimando 
a atuação de um Estado que deve punir. "O direito de punir deslocou-se da vingança do soberano à defesa da sociedade" (FOUCAULT, 2014a, p. 110).

Como dito anteriormente, nesta sociedade burguesa/capitalista de urbanização crescente, vê-se o surgimento de regiões marginais ou periféricas, onde é possível encontrar grupos socialmente segregados, portanto, com dificuldades de inserção aos meios de produção, consequentemente com menor acesso ao capital e, desta forma, a toda uma sociedade de consumo que começa a se formar. Há em suma uma relação entre crime-urbanização-densidade demográfica. Ocorre também que toda esta concentração urbana eleva o número de sujeitos marginais e a dificuldade de controle social. Este será o palco principal para a criação dos "inimigos" da sociedade e também de exploração do poder punitivo, que em última análise opera como instrumento de verticalização social (ZAFFARONI, 2014, p. 46).

Há que se ressaltar uma importante modificação na dinâmica do poder que começa a surgir a partir do século XVIII. Enquanto no medievo poder-se-ia afirmar a existência de um poder sobre o povo - ou corpo social - na modernidade há um poder no povo (FOUCAULT, 2014b, p. 231). Essa alteração é de fundamental importância, pois determinará as novas formas do Estado exercê-lo e controlá-lo, que, em última análise, tenderá sempre à sofisticação, à sutiliza dos processos. E uma das formas de fazê-lo foi criando a ideia do homem médio: constituindo o povo como um sujeito moral, firmando e reafirmando a noção maniqueísta de certo e errado, do homem de bem e do delinquente. Esta moralidade dicotômica será sustentáculo para inúmeras formas de controle social, inclusive, e talvez principalmente, pelo direito penal.

Foi absolutamente necessário constituir o povo como um sujeito moral, portanto separando-o da delinquência, portanto separando nitidamente o grupo de delinquentes, mostrando-os como perigosos não apenas para os ricos, mas também para os pobres, mostrando-os carregados de todos os vícios e responsáveis pelos maiores perigos (FOUCAULT, 2014b, p. 218).

Os indesejáveis são todos aqueles que estão à margem desta nova sociedade moderna, capitalista. Podem estar diretamente vinculados ao aspecto do capital, como os pobres, vagabundos, moradores de rua, desempregados; ou aqueles que detém algum valor considerado negativo para a sociedade, como negros, mestiços, etnicamente em divergência com o ideal daquela comunidade, o estrangeiro, o estranho; ou, também, etiologicamente determinados, como os loucos, incapazes. Na verdade, todos estes aspectos estão intimamente relacionados, há, portanto, uma estigmatização biopsicossocial que constrói os inimigos do bem-estar da sociedade (ZAFFARONI, 2014, 21/25). Ocorre, assim, que a imagem da pobreza une-se a um 
(des)valor e transforma-se numa espécie de doença social que deve ser, de alguma maneira, extirpada.

O Sistema de valores que nele (Modelo Penal) se exprime reflete, predominantemente, o universo moral próprio de uma cultura burguesaindividualista, dando a máxima à proteção do patrimônio privado e orientando-se (...) para atingir as formas de desvio típicas dos grupos socialmente mais débeis e marginalizados (BARATTA, 2011, p. 176).

Em um contexto geral, a criação de inimigos do Estado e da sociedade sempre foi um instrumento útil à sustentação de um poder punitivo paralelo, de um Second Code (BARATTA, 2011, p. 88), ou seja, um modelo penal subterrâneo que legitima certas políticas e atuações arbitrárias, discricionárias. Alguns exemplos saltam aos olhos, como o caso do antissemitismo nazista durante a $2^{\circ}$ Guerra Mundial (ZAFFARONI, 2014, p. 54). Outro discurso que vem moldando e solidificando, ao longo das duas últimas décadas, um novo indesejável é o terrorismo. Tendo como inimigo este novo fato global, diversos Estados vêm tomando medidas para combate-lo, legitimando "guerras preventivas", legislações autoritárias, que violam direitos humanos (ZAFFARONI, 2014, p. 66). O ideal moderno de segurança, nesta sociedade de risco, como configura Beck (BECK, 2010, p. 17), transforma-se no fator de legitimação do uso e abuso do poder.

Para que essas construções abstratas de inimigos sejam eficientes, é preciso que elas realmente gerem a sensação de insegurança na sociedade, que crie um sentimento de medo nos indivíduos ao ponto de cederem por livre e espontânea vontade suas liberdades, suas informações pessoais, sua dignidade, ansiando, assim, por um Direito Penal expressivo, no qual o Estado possa ter maior controle social. Para isso, diferentemente da idade média, com os suplícios, hoje tem-se a publicização do risco, ou seja, a mídia, em lato sensu, fomenta o medo quando alimenta a imagem do inimigo. É importante ressaltar o conceito moderno de risco, que pressupõe uma possibilidade de avaliação de infortúnios futuros, ou seja, esta noção se dá na tentativa de concretizar o ideal moderno de domínio das certezas, buscando evitar e/ou contornar incertezas não previstas (GIDDENS, 2003, p. 33).

Neste sentido, esta ideia de risco surge unicamente com a ascensão da sociedade moderna, capitalista/burguesa, pois ele é um dos responsáveis pela dinâmica do capital, exatamente pelo fato do sistema econômico buscar um controle sobre o futuro, tanto do mercado como, inevitavelmente, da civilização. É um conceito que nasce dos ideais modernos de controle da natureza, de segurança, de previsibilidade/certeza, de uma "vida boa" no geral, a partir da racionalidade científica. O risco é o elemento inevitável presente no mundo, seja ele natural ou social, mas que pode e é contornável através de outros mecanismos como o seguro 
(GIDDENS, 2003, p. 35) e, precisamente no que se refere à criminalidade, o sistema penal, que tem seu poder punitivo direcionado à imagem do inimigo que representa um risco à "vida boa".

De fato, o risco é um paradoxo moderno, pois apesar de ser este elemento inevitável do mundo, portanto indesejável segundo os ideais modernos, simultaneamente é responsável por diversas dinâmicas essenciais para reprodução e manutenção dessa sociedade industrial/burguesa. "De fato o capitalismo é impensável e impraticável sem ele (risco)" (GIDDENS, 2003, p. 36). Desta forma, a criminalidade é tratada, a partir de um second code, não apenas como um fenômeno que deve ser extirpado, ou reduzido ao máximo, da sociedade. Mas também, e talvez principalmente, como fator de controle social e de administração de capital, ou seja, o crime é necessário. No próximo item se abordará o modelo penal maximalista, que pretende concretizar uma segurança social a partir de um poder punitivo máximo, expressivo.

Sustentado por este discurso maximalista, assim como pelo pretenso cientificismo da teoria norte-americana da Broken Windows, encontra-se legitimado e aceito socialmente o programa de Tolerância Zero. Primeiramente a teoria das Janelas Quebradas, divulgada em 1982, argumenta que a mínima infração, quando tolerada, leva a um sentimento de anomia do Estado e, desta forma, o encorajamento para que outros sujeitos cometam delitos cada vez mais significativos. A Broken Windows produzirá um emparelhamento policial alto do Estado, para evitar o mínimo de desordem social.

A política de Tolerância Zero, portanto, pressupõe um Sistema Penal hipertrofiado, uma resposta rápida, violenta e de todas condutas morais que fujam do padrão da identidade constituída pela classe burguesa e por uma sociedade industrial/capitalista - não se tolera nada, por isso tolerância zero. A justificativa para esta exasperação será a defesa social através da afirmação e reafirmação do poder do Estado nos setores onde há valores sociais distintos. Percebe-se que esta dinâmica do sistema penal cumulada com a forma de punição das instituições-prisão serão responsáveis por estigmatizar e segregar os indesejáveis, a provável ameaça ao bem social (BAUMAN, 1999, p. 84).

Em síntese, esta política de tolerância zero demonstra o seguinte silogismo: Pune-se todas as condutas indesejáveis, evitando que elas progridam ${ }^{5}$ para delitos de maior potencial ofensivo; para que isso seja feito é preciso punir mais; assim, para reduzir o índice de criminalidade é preciso aumentar a atuação do sistema penal. Trata-se, portanto, de um discurso

\footnotetext{
${ }^{5}$ Trata-se aqui da ideia da Progressão Delituosa, ou seja, um ato simples, ordinário, medíocre, de violação a uma conduta a priori, moral, por muitas vezes, pode, e segundo a Broken Windows, torna-se paulatinamente uma ruptura grave no tecido da ordem social. Assim, é preciso evitar até as mais tênues e banais condutas marginais.
} 
que possui certo sentido quando ignoramos as minucias sociais, principalmente quando se observa os resultados de sua implementação na cidade norte-americana de Nova York (BELLI, 2004, p. 73). O Estado neste sentido ganha grande legitimidade para a vigilância e repressão (BELLI, 2004, p. 79/82).

Esta política ganhou popularidade em diversos países, incluindo o Brasil que, a partir da década de 90, buscou implementá-la, especificamente o governador do Distrito Federal, Joaquim Roriz, em janeiro de 1999, aplicou a Tolerância Zero e, para sua execução, contratou de imediato 800 policiais civis, como uma forma de resposta à onda de crimes enfrentada (WACQUANT, 2001, p. 20). O discurso foi amplamente utilizado por políticos e pela mídia, que atualmente é caracterizada como sensacionalista, mas que ainda faz sucesso entre as massas (BELLI, 2004, p. 61). O programa era recepcionado e reproduzido como uma solução milagrosa para os problemas de segurança social, ainda mais pelo fato da sociedade, como dito anteriormente ao abordar a sociedade de risco, viver sob uma sensação de insegurança e medo. Os políticos viram no discurso um campo fértil para o marketing eleitoral, fácil de convencer o público, além disso, uma oportunidade para emparelhar o Estado, torna-lo mais ativo, forte, capaz de manter a verticalização social.

\begin{abstract}
Os políticos falam para as massas, exploram o medo crescente e o sentimento de terror causados pelos crimes violentos e por sua divulgação ad nauseam pelos meios de comunicação. Os técnicos da segurança pública, entusiasmados pela experiência de Nova York, tendem a falar para um público mais restrito. Procuram alcançar os operadores jurídicos, as elites governantes, os empresários e as classes médias, os quais, apesar de serem menos vitimados pelos crimes do que as classes desprivilegiadas que habitam as periferias e as favelas, se encontram igualmente aterrorizadas e aparentemente dispostos a apoiar políticas mais assertivas. (BELLI, 2004, p. 63)
\end{abstract}

A partir da implementação deste tipo de política, o sistema penal passa a trabalhar de maneira seletiva, é o chamado Labeling Approach, também denominada de teoria do etiquetamento ou rotulação social (BARATTA, 2011, p. 85). Ou seja, ele vai trabalhar com pressupostos modernos, como a dicotomia maniqueísta, a existência etiológica do criminoso, a clientela preferencial do sistema sancionador. Neste sentido, verifica-se a facilidade de reprodução de discursos preconceituosos, individualistas, de valores de uma determinada classe. Hoje é possível vislumbrarmos o resultado de sua aplicação de maneira geral nos Estados Unidos quando se fala de Race Profiling (BELLI, 2004, p. 75), que é o fato da polícia norte-americana ser majoritariamente racista, uma estigmatização sustentada pela ideologia etiológica-racial. Ao contrário do que a teoria entrega, sua práxis estimula o conflito social, principalmente quando se trata de comunidades distintas, resultando em relações 
segregacionistas, bem como se constrói, paulatinamente, uma imagem negativa da força policial e das próprias instituições do sistema penal (WACQUANT, 2001, p. 24).

Concluindo este primeiro ponto, o Estado Moderno, no caso especifico o Sistema Penal, precisou alterar as dinâmicas punitivas para harmonizá-las ao novo arranjo do poder, que não era mais sobre o povo, mas no povo. Assim, o controle social tornou-se mais sofisticado, sutil e útil, influenciado pela composição da nova sociedade industrial/burguesa, responsável pela aglomeração urbana; pela origem tanto do direito à propriedade quanto pelos crimes desta ordem; a racionalidade cientifica que sistematizou todo o comportamento e ideal modernos, sustentado pelo movimento iluminista; ideais como previsibilidade, segurança, controle da natureza, a busca pela verdade absoluta, a dicotomia entre o bem e o mal, o certo e o errado; a partir deste maniqueísmo, a criação de indesejáveis, ou inimigos da sociedade, àqueles que fogem dos padrões identitários do homem médio. O Sistema Penal utilizou-se destes anseios para se fortalecer, e o encarceramento como uma indústria de controle e produção da delinquência.

\section{CRISE DE LEGITIMIDADE E O BRASIL DE HOJE}

Colocar-se-á em solo crítico certas noções modernas que fundamentaram toda uma dinâmica de atuação do poder Estatal e de organização socioeconômica. O primeiro passo que será dado é evidenciar a inexistência fática da noção de homem comum ou médio, que em síntese seria um modelo ideal de ser dos homens, aquele que deveria ser seguido e alcançado por todos, sendo considerado, portanto, como o homem bom. O homem médio não existe, na verdade sua criação é uma mera abstração que funciona muito bem como forma de legitimar a atuação do sistema punitivo, em outros termos, é um ponto de apoio, um referencial a ser seguido (HULSMAN, 1993, p. 55/56), isto é, um norte a ser seguido pelas instituições criminais que proporciona um enquadramento específico da população que majoritariamente será tocada por ele, ou seja, uma clientela preferencial.

O ideal do homem médio - sendo constituído a partir de valores selecionados por uma classe dominante, como sendo os valores a serem reproduzidos na nova ordem que se propõe, uma ordem ligada à promoção do sujeito da modernidade, sob a égide do estado moderno, destinado a dar suporte, neste sentido e âmbito de discussão, a uma sociedade industrial/burguesa, portanto grupos economicamente privilegiados - possui dois efeitos muito relevantes: a) como referencial que é, ele se torna um modelo a ser buscado por todos. Assim, torna-se parâmetro para o discurso jurídico-penal operar de maneira planificadora, ou seja, a 
partir de um texto legal, constituirá um “dever ser” para o ser-que-ainda-não-é, trabalhando na lógica de um vir-a-ser possível de um ser que, na verdade, jamais será (ZAFFARONI, 2017, p. 19); b) esta dinâmica de adequação social será vislumbrada na colonização dos países marginalizados globalmente. Em suma análise, os valores constituintes do homem médio serão reproduzidos, gerando a perda da identidade cultural própria de cada nação, o denominado colonialismo ou neocolonialismo tecnocientífico (ZAFFARONI, 2017, p. 76).

Trata-se de um fenômeno derivado do poder planetário ou enxertado na sua rede em posição marginal. $\mathrm{O}$ saber das fábricas ideológicas centrais, ao transnacionalizar-se, torna-se disfuncional para o exercício do poder dos sistemas penais marginais, restando, como único caminho para que suas agencias escamoteiem seu poder, a desinformação teórica. Não é em vão, portanto, que os órgãos do sistemas penais latino-americanos favoreçam a reiteração (...) do discurso jurídico-penal mais tradicional (...) dos discursos centrais, em função de um chauvinismo "científico". (ZAFFARONI, 2017, p. 36)

Neste sentido, a noção de homem médio, interagindo e sustentando o discurso jurídicopenal, constituindo os valores modernos centrais de uma determinada sociedade, irá antagonizar os sujeitos entre aqueles que são o-que-se-deve-ser e os que ainda não o são. Estes últimos serão tocados pelas malhas penais para que se tornem o-que-não-são. Contudo, o encarceramento da maneira em que se encontra constituído - não proverá eficientemente esta planificação do sujeito, ao contrário, o sentenciará a jamais ser o-que-se-deve e, desta forma, será renovadamente inserido nas malhas penais, a denominada criminalização secundária. Esta dinâmica do poder de punir dá ao sistema o caráter de perversidade em seu sentido etimológico (ZAFFARONI, 2017, p. 19).

Um dos efeitos da aplicação deste discurso jurídico-penal perverso será a cisão social entre o homem bom e o homem delinquente, ou seja, o mundo preto e branco moderno, o maniqueísmo. Este problema pode ser encontrado nos países centrais do sistema planetário, como o fenômeno do Race Profiling. Contudo, seus impactos são muito maiores nos países marginais pelo fato da distância entre os valores que moldam sua cultura, forma de vida, linguagem, etnia e os valores que constituem o homem comum - que é reproduzido pelo sistema como "dever-ser" - serem superiores aos encontrados nos próprios países centrais, aos próprios sujeitos e valores intranacionais destes Estados. Desta maneira, o sistema punitivo trabalhará numa lógica de extinção do inimigo, daquele indivíduo que está fora da comunidade estatal (ZAFFARONI, 2014, p. 21).

Em nossa região periférica e marginal, este no sentido dos valores a serem acolhidos, na América-Latina, observa-se um histórico de violências e de instabilidades sócio-políticas. Zaffaroni defenderá a ideia de que esta região "é, em substância, o resultado de um formidável 
processo de interação da marginalização planetária, marcada pelo sincretismo. " (ZAFFARONI, 2017, p. 168). Em outros termos, pode-se dizer que os países latino-americanos foram palco de um longo processo de colonização e migração, responsável por fomentar uma multiplicidade cultural extensa, agravando a dinâmica de planificação do discurso jurídicopenal. Em suma análise, há uma confusão que situa o delito como situação de guerra e o infrator como opositor, como inimigo do Estado e Sociedade, uma noção enraizada de hostilidade (ZAFFARONI, 2017, p. 161).

Este será o cerne da deslegitimação do discurso jurídico-penal perverso, é também o foco de crítica na forma de atuação do sistema punitivo maximalista, pois a solução principal para a criminalidade é a hipertrofia deste poder, dos seus órgãos militares, de suas instituições e dos textos legais. Como consequência o que se constata são penas discricionárias, que se desarmonizam com o contexto humanista pós-moderno; uma dinâmica seletiva, que estigmatiza quando passa pelas malhas penais e depois segrega, marginaliza; que não é eficiente na garantia de segurança, inclusive jurídica; e que, ao invés de preservar a liberdade do sujeito, o reprime; ao invés de garantir a vida, mata; ao invés de reeducar o delinquente, o reproduz. Este é o cenário dos países marginalizados, incluindo o do Brasil.

O ponto agora é elucidar a situação especificamente brasileira no que se refere à criminalidade e ao encarceramento. Para isso será utilizado como fonte de dados o relatório de conjuntura $\mathrm{n}^{\circ} 4$, de junho 2018, desenvolvido pelo próprio Estado, tendo como foco os custos econômicos da criminalidade no Brasil ${ }^{6}$. Vale ressaltar que devido à hipertrofia do sistema, da Tolerância Zero, que exige o modelo maximalista penal, os gastos para mantê-lo também são altos; mas além disso, como é uma dinâmica que não soluciona eficientemente o problema do crime, ele está constantemente sendo alimentado, pois necessita crescer para combater, este é mais um ponto problemático e frágil deste discurso jurídico-penal.

Quanto à questão da criminalidade, baseado nos índices de homicídio, o que se coaduna com o posicionamento estabelecido por Zaffaroni ao sustentar a deslegitimação pelos próprios fatos, o fato da morte é inegável, "ninguém seria tolo a ponto de negar que os mortos estão mortos. " (ZAFFARONI, 2017, p. 38/39). O Brasil, que possui 3\% da população global, concentra certa de $14 \%$ dos homicídios mundiais. É um dos mais altos índices, ao lado de países como África do Sul, Ruanda, República Democrática do Congo, estes que também fazem parte do grupo marginalizado do sistema global. Entre 1996 a 2003 houve um aumento de 35 mil a

\footnotetext{
${ }^{6}$ Presidência da República. Custos Econômicos da Criminalidade no Brasil. Conjuntura $n^{\circ}$ 4. Julho de 2018 , disponível em: https://download.uol.com.br/noticias/2018/relatorio/custos-economicos-da-criminalidade-nobrasil-06-2018.pdf;
} 
48 mil homicídios ao ano; entre 2003 e 2007, houve uma queda de 48 mil a 44 mil; a partir de 2008 até 2015 , chegou-se a 54 mil mortes por ano.

No que se refere aos custos econômicos da criminalidade, restará comprovada que maiores investimentos na máquina punitiva não significam aumento de segurança ou redução de criminalidade. É preciso salientar que, naturalmente, os gastos com o poder punitivo tendem a gerar receitas negativas, pois é um sistema que, na realidade brasileira, não produz capital/lucro, e assim deve ser, pois não é este o objetivo da punição e do encarceramento. O problema que se deseja pôr à luz é a administração das verbas públicas, que o modelo penal maximalista exige uma porção cada vez maior. No período de 1996 a 2015 houve um salto nos gastos com segurança pública, de 32 bilhões de reais para 90 bilhões por ano, no nível da União. O mesmo ocorre com a segurança privada, que de 20 bilhões de reais foi para 60 bilhões.

Já quanto ao encarceramento os índices não são nada positivos. No período de 1995 a 2015 houve um aumento de 318,15\% no número de presos. Segundo o INFOPEN ${ }^{7}$ de 2016 a população prisional brasileira é de 726.712 presos, em média (INFOPEN, 2016, p. 08/09). Traduzindo esta taxa para o custeio desta instituição, de 6 bilhões de reais saltou para 16 bilhões. Apesar do sistema prender cada vez mais, não é possível vislumbrar uma realidade com redução dos crimes, pelo contrário, percebe-se que todo o sistema está em uma crise cada vez mais profunda. Outro problema gerado pelo encarceramento e principalmente pelo aumento do número de presos, é que estes sujeitos sob pena restritiva de liberdade, estão fora da sociedade e dos próprios meios de produção, o que em última análise traduz em uma redução da capacidade produtiva geral do país, ou seja, além do sistema em si não produzir capital, ele ainda reduz os níveis e as capacidades de produção.

Em um panorama geral, o custo com a criminalidade elevou cerca de 4,5\% ao ano. Não obstante, a taxa de aprisionamento também se elevou, de 2000 até 2016 um aumento de 157\% (INFOPEN, 2016, p. 12), fato este que não pode ser negado e levanta hipóteses: a) o sistema penal está falhando na redução e inibição dos crimes; b) ou esta punindo mais e de maneira discricionária. Em suma análise as duas possibilidades são verdadeiras e simultâneas. Por fim, é possível visualizar a seletividade do poder punitivo quando nos deparamos com uma população carcerária composta $64 \%$ por negros (INFOPEN, 2016, p. 32). No mais, quanto à escolaridade da população prisional e, consequentemente, da clientela preferencial do poder

\footnotetext{
${ }^{7}$ Os dados do INFOPEN (sistema de informações estatísticas sobre o sistema prisional brasileiro), produzidos pelo Departamento Penitenciário nacional/Ministério da Justiça e Segurança Pública, podem ser encontrados no seguinte endereço eletrônico: http://depen.gov.br/DEPEN/depen/sisdepen/infopen.
} 
punitivo, $51 \%$ não possuem ensino fundamental completo e apenas $9 \%$ concluíram o ensino médio (INFOPEN, 2016, p. 33).

O modelo maximalista penal possui certa lógica em sua maneira de atuação, ou seja, aparentemente funciona efetivamente no combate à criminalidade. Contudo, para conseguir trabalhar na dinâmica da Tolerância Zero, é preciso identificar comportamentos e grupos que se aproximam do que é o criminoso, uma clientela preferencial antagônica àquele homem médio e seus valores. Assim o sistema que nasce e atua é seletivo, mas, além disso, ao ser rápido e intolerante ele se torna discricionário, não harmonizando com os direitos que surgem após a segunda metade do século XX e o neoconstitucionalismo. Na verdade, essa dinâmica tende a agravar os conflitos, como é possível demonstrar com os dados supramencionados, a criminalidade se eleva, o aprisionamento também, consequentemente a população carcerária, assim como os custos econômicos para manter todo o sistema se amplia. A hipertrofia deste poder o deixa menos eficaz, o encarceramento irá falhar em seu objetivo aparente, que é reeducar o delinquente e reinseri-lo na sociedade. Apesar do discurso ter certo nível de sofisticação, na prática ele é problemático.

\section{A TEORIA DE HULSMAN E SUAS PROBLEMÁTICAS PARA O CONTEXTO BRASILEIRO}

De certa maneira, o Abolicionismo funciona oposto à teoria da Broken Windows, às políticas de Tolerância Zero e aos modelos punitivos maximalistas. $\mathrm{O}$ abolicionismo proposto no livro encabeçado por Louk Hulsman denominado "Penas Perdidas: O Sistema Penal em Questão" (HULSMAN, 1993, p. 101) propõe em última análise o fim do sistema penal. É preciso salientar que os poderes punitivos e coercitivos ainda permanecerão como possibilidades do Estado, vigentes sob a sociedade, contudo as bases do modelo de controle estatal, como atualmente estão organizadas e atuantes, seriam reinventadas por completo. A ideia é implementar novas formas de punição - fora do âmbito penal, não as caracterizando como tais, em seu sentido atual - mais sadias no sentido de serem menos danosas ao sujeito e ao corpo social, mas principalmente mais humanizadas, sofisticadas e que, para o autor, potencialmente mais eficazes. "Deixa de aplicar o modelo punitivo, que se tornou ineficaz, para tentar o modelo terapêutico ou conciliatório" (HULSMAN, 1993, p. 101).

Hulsman irá criticar uma série de ideais modernos, alguns acima expostos, que dão forma aos modelos penais convencionalmente tidos como válidos como: os pressupostos maniqueístas; o ideal de homem médio; a relatividade do conceito de crime, assim como sua rasa construção utilizada pelo direito penal, "não há nada na natureza do fato, na sua natureza 
intrínseca, que permite reconhecer se se trata ou não de um crime" (HULSMAN, 1993, p. 63), elaboração teórica fundamental para estruturar e legitimar a ideia de descriminalização, sustentáculo para o abolicionismo. A grande inovação do autor, portanto sua importante contribuição para repensar o funcionamento de tal sistema, a partir de uma perspectiva de solidariedade, é inverter o interesse da sanção penal - na verdade da punição por um outro âmbito administrativo - do Estado para a vítima (ZAFFARONI, 2017, p. 99).

Para sustentar a sua teoria abolicionista, a ideia de uma punição terapêutica e conciliatória, Hulsman inverte o polo da legitimidade e do interesse da punição. O sujeito que teve violado seu bem jurídico protegido pelo Estado possui, ou deve, neste caso, ser o real interessado na punição e atuar diretamente sobre ela. De certa forma a legitimidade deixa o âmbito do Estado e da construção moderna de corpo social, que sustenta aquele, e migra para o(s) sujeito(s) que expressamente foram atingidos e lesionados pela conduta do autor. "o sistema penal rouba o conflito das pessoas diretamente envolvidas nele." (HULSMAN, 1993, p. 82). De acordo com esta teoria, a pena contém dois elementos: a) a relação de poder entre quem pune (Estado) e quem será punido, sendo o primeiro reconhecido pela vítima como legítimo para tal atuação; b) elementos de penitencia e sofrimento impostos pela aplicação da punição, mas que, na prática, em regra, não acrescentam em nada à realidade do vitimado.

Outro importante ponto, tendo em vista a abolição do sistema em tela, mas não apenas neste cenário, é a defesa da eliminação do vocabulário decorrente do conceito de "crime", ou seja, é preciso extirpar palavras como "criminoso", "criminalidade". A ideia por trás disso é o peso estigmatizador que tais terminologias possuem, afetando, portanto, a imagem do autor da conduta que, agora, não mais pode ser denominada criminosa. Hulsman dá exemplos interessantes como o termo "serviçal" para "empregada doméstica", "concubina" para "companheira", o efeito é tornar menos pejorativo o necessário rótulo que implica a nomenclatura e categorização das coisas (BACILA, 2015, p. 135).

Para o abolicionismo de Hulsman também é fundamental romper com o sedimentado entendimento de "gravidade" das condutas. Que o sistema penal deva agir em todas as condutas delituosas, mas, principalmente, nos casos graves e na proporção devida, ou seja, a ideia de uma certa progressão delituosa. No caso abolicionista, esta ideia fica de certa forma em aberto, assim como a reação sobre os atos, pois o legitimado para exercer o poder punitivo é o interessado, o real afetado pela conduta. Assim, ele irá analisar e posteriormente mensurar a noção de "gravidade" e "reação" (BARATTA, 2011, p. 93). Na verdade, a partir da ruptura do mito do Direito Penal igualitário, fica claro que realmente a noção de danosidade das condutas 
não determina a reação do sistema, "O status de criminoso é independente da danosidade social das ações e da gravidade das infrações" (BARATTA, 2011, p. 162).

Fica claro, assim, que o ponto nevrálgico do pensamento abolicionista está em “devolver às pessoas (diretamente) envolvidas o domínio sobre seus conflitos" (HULSMAN, 1993, p. 102). Defende-se a necessária relação entre o autor e a vítima, um encontro cara-a-cara que possibilita um diálogo que, no entender do autor, leva a um esclarecimento dos fatos, dos motivos, dos danos, propiciando uma espécie de acordo mútuo. Desta forma, não existe uma linha fixa de punibilidade, ao contrário, as decisões sobre a sanção deveriam ser construídas especificamente para o caso concreto e somente pelos sujeitos agredidos. O Abolicionismo propõe uma "reconstrução de vínculos solidários de simpatia horizontais ou comunitários" (ZAFFARONI, 2017, p. 104). Para Hulsman esta é a ideia de uma pena humanista e realmente eficiente, ressaltando que sua aplicação dar-se-ia em outro âmbito jurídico, pois o penal seria extinto.

O ponto nevrálgico para a crítica à Hulsman é que ele construiu um complexo teórico que na prática se mostra ingênuo. Ocorre que o abolicionismo, para ser aplicado, concretizado e eficiente, na medida do possível e à sua maneira, não necessita apenas da extinção do sistema penal e da releitura da noção de poder punitivo. Na verdade, exige-se algo muito mais complexo, uma reestruturação de todo campo social, de todas as instituições que interferem diretamente no funcionamento do corpo comunitário. Isso, pois sua teoria, como visto, inverte o polo de legitimidade dando grande poder aos sujeitos e, aqui, não se está entrando no mérito desta inversão, mas apenas reconhecendo as dificuldades de fazê-la, dos riscos e problemas que dela podem derivar se não existir uma consistente estrutura social.

Em um segundo plano, afirmar que a resposta penal é de interesse interpartes é recusar, o que Hulsman recusa, a ideia de que valores com elevado grau de interesse social merecem proteções mais eficientes - que a gravidade do bem jurídico protegido deve ser desprezada e finalmente que a subsidiariedade penal é algo a ser desprezado, pois dá-se conta de tudo sem o penal. Este é um ponto crucial, pois resulta numa relativização dos bens jurídicos, no caso, constitucionais, a serem protegidos em graus diversos. Seu impacto incide diretamente na inversão dos polos e uma dinâmica punitiva baseada na interação direta entre o autor da conduta delituosa e o sujeito que teve seu bem jurídico violado, exigindo que ambas as partes estejam muito bem orientadas e dispostas a chegar a um consenso.

Este papel, em certo sentido mediador, do Estado é incompatível com certas realidades, principalmente as dos países marginalizados, como o Brasil. Consuetudinariamente o corpo 
social enxerga no poder Estatal, mais precisamente no Judiciário, uma espécie de pátrio poder, responsável por resolver os míseros conflitos sociais, que não encontra frutífera solução fora do âmbito jurídico-coercitivo. Trata-se aqui de uma defasagem que Huslman enfrenta ao ler a sociedade brasileira e sua realidade atual e histórica, enquanto um país que se encontra à margem do sistema planetário.

Desta maneira, a crítica aqui elaborada em face do abolicionismo de Hulsman concentra-se nas dificuldades da dinâmica por ele defendida, que Zaffaroni sintetiza no lema “chegar ao próprio conflito" (ZAFFARONI, 2017, p. 99). Exige-se dos indivíduos um grande nível de comprometimento sócio-político, um amadurecimento intelectual profundo dos sujeitos que devem estar abertos principalmente na reflexão do e sobre o Outro, tendo em vista a densa subjetividade que a punição exige neste modelo. Isso sem entrar no mérito - já não no intento de crítica, mas de apreciação prática - de como serão reorganizados o sistema e o direito penal uma vez extinto, ou seja, quais os lócus jurídicos, legislativos que recepcionarão aqueles primeiros, a criação de novas instancias estatais para suprir as necessidades que, por ventura, possam surgir.

\section{O MODELO TEÓRICO DE ZAFFARONI}

Para o autor de Em busca das penas perdidas, uma das obras centrais de seu pensamento, que aqui será amplamente utilizada, o minimalismo penal deve ser visto como um caminho ao abolicionismo, mas, através da interpretação de seu arcabouço teórico, não se deve pensar neste modelo para ser ou concretizar, eventualmente, o abolicionismo. O que Zaffaroni constrói tem por objetivo organizar, reformar, modificar um estado-de-coisas posto para que permita a relegitimação do sistema punitivo como um todo - suas instituições judiciais, executivas, legislativas e também não judiciais -, a partir disso os resultados alcançados com a redução da criminalidade e, além disso, das discricionariedades é que se vislumbrará, de maneira quase natural, a opção de implementar um abolicionismo, não idêntico, também, ao construído por Hulsman. É neste sentido que Zaffaroni afirma que o "objetivo mais imediato deve dirigir-se para a redução do número de mortes e a geração de espaços de liberdade social" (ZAFFARONI, 2017, p. 175), ou seja, a reconstrução de um tecido social comunitário.

Como dito, Zaffaroni buscará formular uma teoria que captura especificamente a realidade latino-americana, sendo este o fator que o fez ser aqui o marco teórico. Contudo, isso não significa que seu pensamento não utiliza paradigmas epistemológicos de autores que fogem dessa realidade. Pode-se dizer, na verdade, que Zaffaroni possui três sustentáculos principais: 
a) a teoria marxista, selecionando alguns poucos autores, incluindo Baratta, relacionando a criminalidade e/ou criminalização com o sistema de produção capitalista; b) o interacionismo simbólico e a fenomenologia, que o auxiliará a sustentar a reprodução da "delinquência" na instituição-prisão, bem como delimitar uma realidade objetiva do fenômeno; e, por fim, c) a teoria foucaultiana do poder-saber, da microfísica do poder e das instituições de sequestro. $\mathrm{O}$ autor não irá simplesmente misturá-las produzindo algo, no mínimo, contraditório, mas sim articulá-las à sua maneira, inclusive assinalando as limitações teóricas destas construções, para que o permita observar sob óticas diversas o fenômeno como um todo, ou seja, diagnosticando a deslegitimidade do sistema a partir de caminhos que se convergirão.

O ponto inicial, por assim dizer, do pensamento de Zaffaroni para construir um sistema punitivo, um discurso jurídico-penal legitimado, ou seja, um modelo adequado à situação político-social, é o realismo marginal que possibilitará iluminar as problemáticas dos países marginalizados e explicar, a partir de um movimento paulatino e histórico de colonialização a forma como não apenas o sistema penal, mas toda a realidade dos países da América Latina foi construída. Zaffaroni irá esclarecer o que compreende por "realismo": a) o sentido material do mundo e externo a nós; b) como um atributo do "mal", ou seja, ele realmente existe, como uma problemática cultural latino-americana; c) para uma aproximação dos fenômenos do sistema penal; d) uma leitura capaz de construir um modelo que não seja ideal, idealista, mas adequado à realidade; e) indicando as violações existente na região marginal contra a vida humana (ZAFFARONI, 2017, p. 161/162). Isso já permite verificar o ponto de partida, isto é, algumas problemáticas que serão trabalhadas, bem como o que se pretende construir.

Assim como esclareceu as formas interpretativas do "realismo", Zaffaroni destrincha a expressão "marginal" que por ele será utilizada e comporá o realismo marginal: a) uma ideia de localização periférica do poder planetário; b) relação de dependência ao poder central; c) as populações localizadas nessa região submetida ao poder central, em específico a América latina; d) e, por fim, uma configuração "marginalizada" destas populações a partir da incidência cultural, em suma ideológica, proveniente de um colonialismo, neocolonialismo e tecnocolonialismo (ZAFFARONI, 2017, p. 164/166). Pode-se sintetizar a ideia do realismo marginal como uma ferramenta capaz de pôr à luz tanto um processo histórico de dominação cultural, econômico e político, bem como o desenvolvimento dos sistemas penais a partir deste espelhamento e influência coercitiva, em certo sentido, dos países centrais, assim como um diagnóstico da facticidade dos países marginalizados, dentre eles o Brasil. 
O nosso realismo marginal pretende contemplar uma aproximação com a realidade objetiva do sistema penal que, através das estruturas logico-reais, possa também, servir de base para um novo discurso jurídico-penal que paute as decisões das agencias judiciais como parte de uma tática orientada para a mesma estratégia delimitadora do campo do saber criminológico. (ZAFFARONI, 2017, p. 172)

A facticidade diagnosticada por Zaffaroni, que compõe o arranjo do realismo marginal, dos países marginalizados, em especifico os latino-americanos, dentre eles o Brasil, se constitui historicamente a partir de movimentos de colonialização. É neste sentido que a ideia de colonialismo, neocolonialismo e tecnocolonialismo ganha suma importância em seu pensamento. Vale, portanto, lançar luz sobre estes conceitos, assim como, após, assinalar algumas observações quanto às dinâmicas que lhes integram. Para Zaffaroni o colonialismo é um movimento predominantemente do século XV tendo como fundamentação para a subordinação e inferiorização de outras civilizações as tradições teocráticas; por outro lado, o neocolonialismo se inicia no século XVIII a partir de outros discursos, racionalistas, modernos, cientificistas, positivistas, vinculados aos estudos biológicos, o que em última análise chamará de eugenia (ZAFFARONI, 2012, p. 110). O neocolonialismo, inclusive, segundo o próprio autor, foi um instrumento utilizado pela Alemanha nazista.

Dito de outro modo, o neocolonialismo, após ter sido utilizado de maneira enfática durante a Segunda Guerra mundial, especialmente pelos nazistas, produziu em escala um fenômeno que antes era apenas pontual, os campos de concentração, que, nas palavras de Zaffaroni "han sido legitimados con racionalizaciones provenientes del racismo positivista" (ZAFFARONI,2012, p. 109). Aqui vale uma observação e, talvez, crítica no sentido de como o colonialismo ou o neocolonialismo funcionam, isto é, suas dinâmicas de poder. O que se pretende não é invalidar a construção de Zaffaroni, mas sim esclarecer alguns pontos permitindo sua ampliação. Zaffaroni elabora, a partir das instituições de sequestro de Foucault, o conceito de instituição-colônia que caracterizaria a nossa região marginal, comportando instituições menores, como a prisão, inclusive afirmando que a instituição-colônia seria um grande campo de concentração, sendo formados pelos países periféricos e mantidos, a partir de uma reprodução vertical, pelos países centrais (ZAFFARONI, 2017, p. 74/78).

A observação que se fará é quanto à produção e resultado que decorre das dinâmicas de atuação do colonialismo ou neocolonialismo. Primeiramente fica clara a correlação entre podersaber produzida por ambas as formas de colonialismo, segundo Foucault "não há exercício de poder sem uma certa economia dos discursos de verdade que funcionam nesse poder, a partir e através dele." (FOUCAULT, 2018, p. 22). Contudo, é preciso cristalizar que seu funcionamento 
produz dois resultados distintos: a) primeiramente, segundo Zaffaroni, pode-se interpretar um movimento centrífugo, isto é, de afastamento, de cisão, por fim, de segregação - o homem bom e o homem mal; o homem médio e o doente, o delinquente, o inferior, devendo sempre estes últimos serem desagregados do meio social central e levados às periferias - que possibilita a produção de instituições de sequestro, de campos de concentração, da própria instituiçãocolônia de Zaffaroni; b) segundo, a própria ideia de controle social, talvez mais próximo da ideia básica de colonialização, ou seja, a destituição de uma identidade a partir da inserção de identidades alienígenas, o que se faz a partir dos discursos de verdade. Aqui não se trata de um movimento centrífugo, muito menos centrípeto, mas sim da própria ideia de inferiorização e subordinação civilizatória, buscando, em suma, uma dominação ideológica.

Foi absolutamente necessário constituir o povo como um sujeito moral, portanto separando-o da delinquência, portanto separando nitidamente o grupo de delinquentes, mostrando-os como perigosos não apenas para os ricos, mas também para os pobres, mostrando-os carregados de vícios e responsáveis pelos maiores perigos. (FOUCALT, 2014, p. 218).

É interessante, neste sentido, que o colonialismo em Zaffaroni possui este duplo significado que não é dado de modo explícito em sua obra, mas quando sustenta o campo de concentração latino-americano e, outrora, a reprodução ideológica, constituintes do realismo marginal, esses fatores estão implícitos inevitavelmente. Um exemplo de como esse mecanismo trabalha atualmente pode ser observado com o fenômeno do terrorismo. $\mathrm{O}$ discurso terrorista surge na região central e é assimilado pela região marginal que adere ao discurso e o fortalece, como um discurso de verdade. Por outro lado, o terrorismo produz um movimento centrífugo, pois há um rosto previamente definido, o terrorista, o inimigo, a hostilidade é caracterizada e divulgada, isso produz as zonas de concentração, não nos mesmos moldes que os campos nazistas, mas a segregação é cristalizada. Incide, assim, diretamente nos valores sociais que, paulatinamente, vão se reconfigurando. Outro exemplo seria a "satanização", nas palavras de Zaffaroni, do marxismo, que na américa latina designa "tudo o que constitui ou ameaça constituir um contra poder à verticalização militarizada de nossas sociedades periféricas" (ZAFFARONI, 2017, p. 36), portanto, assimilado com certo receio e até desprezo nos discursos e ideologias regionais.

É a partir deste estado-de-coisas diagnosticado por Zaffaroni que se explicará o funcionamento deslegitimado, arbitrário, violento do sistema punitivo na região. Trata-se de um discurso perverso, pois mesmo percebendo a impossibilidade de adequar-se à planificação das estruturas jurídico-penais centrais, ainda insiste na ideia, reproduzindo-a como um discurso 
de verdade. A crítica é que não se pode desentender-se do ser, isto é, refugiar-se ou isolar-se de um "dever ser" (ZAFFARONI, 2017, p. 19). Em outros termos, é preciso pensar um "dever ser" próprio do ser que é, e não se espelhar em discursos universalizantes, principalmente quando tais discursos compõe um arranjo colonialista histórico.

Antes de abordar propriamente o modelo teórico penal de Zaffaroni, vale voltar os olhos para a reprodução ideológica, uma vez que, para o pensamento deste autor, a manutenção dos discursos perversos são um ponto chave para repensar o sistema punitivo. Para Zaffaroni os mass mídia são grandes criadores de ilusão que atingem a população impedindo-a de perceber a "falácia" dos discursos jurídico-penais, distinguindo dois níveis e formas de atuação: a) transnacionalizado, que se refere ao material produzido por estes meios, bem como à substancia deste material, que para o autor, em sua maioria, projeta uma ideia maniqueísta, um sentimento de insegurança pela existência de um "mal", assim como um certo desprezo pela vida e dignidade humana; b) o nível das conjunturas nacionais, que produzem, em suma, materiais sensacionalistas, com discurso e campanhas rasas de "lei e ordem", a necessidade de se fazer "justiça" a qualquer custo, provocando uma indignação moral e, por outro lado, a ideia de eficácia do sistema em face de certas ameaças ao bem estar social (ZAFFARONI, 2017, p. 128).

Portanto, para Zaffaroni, a mass mídia é um dos pontos nevrálgicos de reprodução ideológica e sustentação do discurso deslegitimado do sistema punitivo, uma vez que produzirá uma criminologia midiática, ou seja, os sujeitos constroem e aderem a uma "visión de la cuestión criminal" (ZAFFARONI, 2012, p. 216) distorcida. Ele produzirá e reproduzirá, este último especificamente nas realidades marginais, os estereótipos que serão estigmatizados, rotulados e, posteriormente, segregados socialmente - aqui uma noção de criminalização primária - bem como tocados pelo sistema penal, agregando na constituição do ser, em sua identidade social, mais um (des)valor (ZAFFARONI, 2012, p. 218/219). É neste sentido que uma das propostas de Zaffaroni, para seu modelo teórico, é a intervenção nos conteúdos produzidos por esta agência: a) "neutralização do aparelho de propaganda violenta do sistema penal" nos meios de comunicação social; b) controle técnico sobre as notícias, a fim de evitar a publicização de mensagens falaciosas - uma ideia que se aproxima da fake news - assim como substâncias que podem instigar violência (ZAFFARONI, 2017, p. 175). Trata-se de um delicado debate que o presente trabalho não pretende entrar no mérito ${ }^{8}$.

\footnotetext{
${ }^{8}$ Aqui é preciso considerar que este caminho pode nos levar à ideia de censura, de restrição à liberdade de expressão. Zaffaroni buscará defender sua construção, fazendo algumas distinções hipotéticas de casos práticos e como deveriam ser lidos adequadamente em seu modelo de pensamento. De qualquer forma, entre casos hipotéticos e práticos, há uma distância relevante quando na práxis cotidiana. Nós reconhecemos a importância de
} 
La urgência de respuesta concreta y coyuntural lleva a dos grandes contradicciones etiológicas, pues por un lado atribuye la criminalidade a una decisión individual, y por otro estigmatiza a un conjunto com caracteres sociales parecidos; además, proclama una confianza absoluta em la función preventiva disuasoria de la pena, pero al mismo tempo promueve la compra de todos los médios físicos de impedimento y defensa. Como la emotividad impide que el destinatário perceba las contradicciones, los controles electrónicos y mecânicos han aumentado en forma impresionante. (ZAFFARONI, 2012, p. 225)

Além da mass mídia há outras instituições, ou nas palavras de Zaffaroni, "fábricas ideológicas de reprodução" e assimilação, como por exemplo a própria universidade, ou os meios de produção de capital. A mass mídia compõe um tecido complexo, mas é parte fundamental para qualquer repensar, não apenas na criminologia. Outro fator são as "agências executivas" do sistema penal, que possuem alto poder configurador, não sendo instituições judiciais, como o aparato policial e serviços de militarização semelhantes, que são moldados a partir de um discurso externo moralizante, ou seja, uma ideologia central, importada, e que em sua práxis busca reproduzi-la. Inclusive com atuações corruptas, agindo em uma abstrata legalidade, mas simultaneamente contra a mesma (ZAFFARONI, 2017, p. 136/137), como por exemplo, os casos de organizações milicianas, uma espécie de instituição paraestatal.

Dando um passo adiante na proposta de modelo mínimo penal, Zaffaroni irá tecer duas considerações base para uma resposta marginal adequada, que também podem ser vislumbradas em outras teorias no mesmo sentido, com construções similares. Primeiramente o que o autor denominará de imperativo jus-humanista, em outros termos, uma sólida e factual harmonia com os direitos humanos, transformando o próprio sistema penal em uma ferramenta para garantilos, uma vez que não se pode considerá-los conquistados e concretizados devido, apenas, às cartas constitucionais e internacionais que os positivaram (ZAFFARONI, 2017, p. 147/149). Neste sentido, a resposta contém também um imperativo ético - se aproximando, inclusive, do pensamento kantiano - uma vez que a realidade marginal mostra um contexto inverso do proposto pelo discurso, uma proposta, portanto, de certa forma, otimista, pois busca quebrar um paradigma perverso posto e reproduzido, diminuindo a violência, matando paulatinamente uma visão maniqueísta e do "mal”, bem como valorizando ideais humanistas (ZAFFARONI, 2017, p. 153/156).

Portanto, a resposta ao discurso jurídico-penal deslegitimado deve estar pautado pelo que fora acima exposto. Assim, Zaffaroni irá construir o seu modelo a partir de elementos que 
legitimam um novo discurso. Estes servem de bases para a estruturação dos princípios, que mais à frente serão abordados, do modelo penal construído. O que deve ser analisado é: a) o exercício de poder do sistema não pode ser verticalizante, bem como simplesmente importado ou assimilado a partir de uma neocolonialização; b) é preciso repensar a pena, sua função e aplicação. É importante construir um arcabouço penal próximo à realidade social conflitiva, e não idealista, pois este dificulta uma leitura pragmática levando o sistema, em suma, à esquizofrenia; c) "elementos negativos" que produzem horizontes de projeção epistemológicos nos quais o sistema deverá atuar, neste âmbito, especificamente, é delimitado pelas penas e seus conceitos, a partir da atuação legislativa. Trata-se aqui de equilibrar estes horizontes de projeção, aumentando ou reduzindo o poder das agências vinculadas ao sistema (ZAFFARONI, 2017, p. 182/184).

É válido ressaltar que, talvez, o ponto de maior relevância é o embate idealista-realista e as características de cada um neste âmbito de discussão. Um modelo penal idealista constróise de maneira fechada, determinista, "imutável", capaz de ter respostas prontas, previamente construídas, para quaisquer situações, assim é um modelo preciosista que prevê respostas adequadas à todas as circunstancias fáticas. Por outro lado, a construção realista é aberta, mais maleável às mutações, "apresenta uma quota de incerteza" exatamente por não carregar respostas prontas para tudo, por estar conectada com a facticidade e mundialidade, de certa maneira, mais pragmática (ZAFFARONI, 2017, p. 187). Dito de outra forma, enquanto o modelo idealista busca intervir no mundo e lê-lo a partir de discursos ideais, submetendo a realidade à idealidade - tendência moderna - o modelo realista incorpora os dados ônticos, estruturando-se a partir do mundo concreto - movimento fenomenológico. Mesmo que sua leitura seja mais limitada e incerta, é mais precisa e adequada, capaz de garantir discursos jurídico-penais legítimos, este é o caminho de Zaffaroni.

Neste sentido se estruturará o modelo teórico penal de Zaffaroni que traz, também, um caráter garantista, pois fortalece a presença das garantias penais no sistema, não apenas como princípios norteadores, mas como uma ferramenta de limitação da irracionalidade da violência geradas pela sua prática. Podemos sintetizar este pensamento no princípio "mínima violação/máxima realização”, esta é a regra do minimalismo de Zaffaroni, a forma como o sistema deverá agir, um compromisso sólido com as garantias penais e, consequentemente, com os direitos humanos (ZAFFARONI, 2017, p. 235).

Zaffaroni irá construir alguns princípios basilares e sintetizadores de todo o arcabouço teórico supramencionado, isto é, princípios necessários para um discurso jurídico-penal 
adequado e um funcionamento não mais perverso do sistema, limitando as violações que este provoca, bem como reduzindo paulatinamente os índices de criminalidade social. Portanto, lançar-se-á luz sobre estes pontos relevantes do modelo teórico de Zaffaroni, dividindo-os em dois grupos, sendo eles ${ }^{9}$ :

1) Princípios de caráter formalista: Tem por objetivo a delimitação formal da constituição e dinâmicas de atuação do sistema penal.

a) Princípio de reserva legal ou de existência máxima de legalidade em sentido estrito: Pugna pelo máximo respeito à legalidade da pena, tendo em vista que esta será repensada a partir do resgate do mundo concreto.

b) Princípio da máxima taxatividade: Todos os tipos penais devem estar claramente determinados, ou seja, não deve haver tipos penais brancos, sem limites certos. Zaffaroni também defende a proibição de analogia das leis penais.

c) Princípio da irretroatividade: A conduta a ser punida deve possuir uma lei penal abstrata previamente determinada e com efeitos ex nunc.

d) Princípio da Máxima subordinação à lei penal substantiva: Tendo em vista a ideia de Zaffaroni que o maior volume de discricionariedades e violações aos direitos dos sujeitos ocorrem em agências que estão fora do controle do Direito Penal por exemplo agências executivas como a polícia, e executiva de pena como a prisão - a partir da reconstrução do sistema penal a partir dos moldes postos por este modelo, quaisquer lei, material ou processual, que impacta na limitação de direitos deve subordinar-se às mesmas delimitações do sistema punitivo.

e) Princípio da representação popular: Leis penais devem ser elaboradas pela agência legislativa diretamente norteada pelo campo constitucional e com representação popular.

2) Princípios de caráter humanista: Direcionados à atuação prática do sistema, sempre com a preocupação humanista e garantista, norteados pelos direitos humanos e a constituição.

a) Princípio da limitação máxima da resposta contingente: Prevê uma atuação negativa da agência judicial frente a uma lei penal introduzida sem o devido

\footnotetext{
${ }^{9}$ Todos os princípios estão referenciados em: (ZAFFARONI, 2017. p. 239/242)
} 
respeito constitucional, a participação popular e técnico. Assim o judiciário tem o dever de declará-la inconstitucional.

b) Princípio da lesividade: O sistema punitivo somente pode atuar quando há bem jurídico penal violado. É preciso ressaltar o papel de ultima ratio do modelo penal mínimo.

c) Princípio da mínima proporcionalidade: Aqui também está presente a ideia da ultima ratio, uma vez que o sistema não deve agir em fato insignificante, com baixa lesividade ou que viole bens jurídicos menos relevantes, que não sejam penais.

d) Princípio do respeito mínimo à humanidade: Próximo ao perdão judicial, previsto no artigo $121, \S 5^{\circ}$, do Código Penal, relativo ao homicídio culposo. Contudo, deve ser aplicado de maneira mais ampla, isto é, quando o sujeito que cometeu o delito padeceu também dos fatos, ou em razão das circunstancias também fora lesionada em alguma medida, o exercício do poder pode dispensar a pena ou imputa-la no mínimo legal.

e) Princípio da idoneidade relativa: A partir da ideia que a intervenção penal não soluciona os conflitos, mas apenas os pune, reprimindo-os, as agências legislativas não podem oferecer soluções simbólicas, mas sim caminhos que comunguem um trabalho coletivo.

f)Princípio limitador da lesividade à vítima: O sistema penal não deve intervir quando esta possa acarretar maiores prejuízos, danos à vítima, tendo em vista a margem natural de irracionalidade do sistema.

g) Princípio de transcendência mínima da intervenção punitiva: A irracionalidade do sistema inevitavelmente implica numa transcendência da intervenção punitivo no sujeito, provocando, por exemplo, a construção de rótulos, estigmas negativos. Assim, o poder deve ser exercido de modo que evite ao máximo essa violência irracional e natural do sistema.

É possível assinalar, após uma interpretação, os pontos nevrálgicos que guiam o sistema construído a partir desta base teórica ao minimalismo penal, e também, ao contrário do que pode se pensar, a efetiva redução da violência, da criminalidade. Trata-se primeiramente de reconhecer os problemas derivados do colonialismo e neocolonialismo, permitindo observar o controle social e a reprodução destes discursos como verdadeiros. Além disso, importante resgatar o mundo concreto, a facticidade própria da realidade latino-americana, possibilitando 
reconstruir um horizonte de projeção adequado no qual o sistema efetivamente deverá agir e, inclusive, impedir ou delimitar a atuação de outras agências metajurídicas. Por estas razões, bem como por pautar-se num discurso humanista e garantista, nos quais o sistema deve guiarse, este arcabouço harmoniza com o constitucionalismo vigente no Brasil, o que será mais explorado no próximo item.

\section{O MODELO ADEQUADO AO CONSTITUCIONALISMO BRASILEIRO: DIÁLOGO COM A HERMENÊUTICA FILOSÓFICA.}

Utilizou-se como marco teórico Raúl Zaffaroni, analisando seu modelo penal minimalista e assimilando-o como ponto de partida adequado para um repensar criminológico na américa-latina, nos países marginalizados, dentre eles o Brasil. A construção que fora realizada até aqui já indica muito o estado-de-coisas que se harmoniza ao constitucionalismo e deve ser concretizado. Contudo, precisamente este fenômeno não fora analisado de maneira adequada. Este será o desafio deste item, isto é, trabalhar o constitucionalismo à luz da realidade brasileira e da contemporaneidade, ainda assim mantendo o foco no âmbito criminal.

O movimento constitucional brasileiro é complexo, podendo dividi-lo brevemente em três momentos: a) O Constitucionalismo do Império; b) o Constitucionalismo da primeira república; c) O constitucionalismo do Estado Social (BONAVIDES, 2013, p. 361). Quando devidamente trabalhado é possível notar as intempéries que este fenômeno, não linear, sofreu ao longo das décadas ${ }^{10}$ até a criação e vigência da carta constitucional de 1988, esta que será o paradigma de análise para a perspectiva minimalista de Zaffaroni. De qualquer maneira não se trata do fim da história. Na verdade, a nova Constituição inaugurou problemáticas sofisticadas e, desta forma, difíceis de serem sanadas, exigindo, em última análise, uma nova forma de racionalizar o texto constitucional, sua relação com os diplomas infraconstitucionais e, por fim, sua correlação com o mundo ôntico, isto é, o resgate do mundo concreto e consequentemente os sentidos, é o retomar o conhecimento a partir do ser.

A Constituição da República de 1988 inaugurou o chamado Estado Democrático de Direito - como previsto em seu preâmbulo - que, segundo Bonavides, pertence a este terceiro momento constitucional, mas seu caráter não é apenas social. A diferença entre o social e o democrático é sutil, mas extremamente relevante. Lenio faz uma distinção quanto ao papel interventivo desses modelos, o primeiro possui um caráter assistencial, enquanto o segundo de

${ }^{10}$ O trabalho não comporta a análise deste vasto e complexo movimento, assim, para mais detalhes ver: CARVALHO, José Murilo. Cidadania no Brasil: O longo caminho. 
função social (STRECK, 2014, p. 68). Não se trata de uma maior intervenção do Estado, mas sim mais ativa e eficiente. O Democrático possui instrumentos garantidores de direitos fundamentais, ou seja, não apenas os positiva na Constituição, mas busca concretizá-los, alterando o status quo social, trata-se aqui de um plus normativo (STRECK, 2014, p. 100). Ainda, Bonavides tece que a "Constituição do Estado Social na democracia é a Constituição do conflito" (BONAVIDES, 2013, p. 380), e realmente é, visto que a Constituição possui um papel contra majoritário, devendo inserir na política social e do Estado a preocupação legítima com grupos minoritários e vulneráveis, impondo ao ordenamento infraconstitucional a elaboração e/ou adaptação de instrumentos, programas e políticas capazes de consagrar direitos fundamentais.

É preciso abordar mais a fundo o que caracteriza este atual paradigma constitucional e quais os desafios por ele posto e enfrentado. Para tratá-lo usar-se-á a terminologia neoconstitucionalismo entendido como uma resposta - e um modelo de engenharia do poder e organização do Estado - tanto do Estado liberal quanto social - aqui é perceptível a limitação de Bonavides ao caracterizar o atual momento como "Estado Social" -, isto é, em última análise, da estrutura constitucionalista originária, desenvolvida, norteada e limitada ao positivismo jurídico, à legalidade. Trata-se, assim, de um novo paradigma, tendo, portanto, caráter ruptural (STRECK, 2016a, p. 01).

A questão é que o positivismo se construiu sobre um total legalismo, isto é, um "direitoenquanto-sistema-de-regras" (STRECK, 2016a, p. 04), proporcionando um esquecimento da facticidade do mundo, que ao mover-se naturalmente, impôs casos práticos e problemáticas que não foram adequadamente assimiladas pelo direito. Trata-se do predomínio do idealismo frente ao realismo. Fenômenos como a discricionariedade judiciária, e a esquizofrenização do próprio sistema - tema este já trabalhado anteriormente - são problemas que devem ser enfrentados a partir de perspectivas que deixem de lado tanto o jusnaturalismo quanto o positivismo clássico (SIVLA FILHO, 2017, p. 105). Tais problemáticas são oriundas de uma leitura inadequada do texto constitucional, que não se comunica adequadamente com as instituições vigentes e, mesmo, diplomas normativos, como o direito penal. É este um dos pontos de conexão do pensamento de Zaffaroni com o neoconstitucionalismo, a necessidade de desenvolver um modelo penal menos idealista e mais realista.

Portanto a vigência da Constituição da República de 1988 não trouxe simultaneamente ou facilmente a ruptura com o paradigma positivista, mas ao contrário, trouxa à luz as limitações jurídico-políticas do Estado brasileiro, consequentemente do sistema penal. Todas as novidades 
trazidas pelo Estado Democrático e pela Constituição não foram devidamente implementadas e efetivadas. Encontramo-nos em tempos paradigmáticos diversos, ou seja, as instituições e a própria sociedade podem ser consideradas modernas em seus pressupostos fundacionais por não terem se desgarrado das amarras do positivismo, que não dialoga adequadamente com a pós-modernidade. Ainda se caminha na modernidade enquanto nossa Constituição de 1988 irradia um dever-ser contemporâneo. De certa forma, ainda se faz uma leitura inadequada da carta constitucional em um país de modernidade tardia (SILVA FILHO, 2017, p. 90/91).

A partir desse arcabouço teórico e jurídico também é possível perceber a deslegitimidade do sistema penal e, por conseguinte, a necessidade de elaborar um modelo capaz de resgatar o mundo ôntico e trabalhá-lo adequadamente. É nesse sentido que a hermenêutica filosófica tem papel fundamental para este rearranjo; em síntese o que se busca é sobrepor o esquema epistemológico moderno "sujeito-objeto" - e consequentemente o solipsismo - tendo em vista seu forte vínculo com correntes modernas, como o jusnaturalismo e o positivismo clássico - perspectivas que não se adequam ao neoconstitucionalismo, podendo produzir, por exemplo, a esquizofrenização do direito e uma discricionariedade interpretativa. Assim, pretende estabelecer o denominado "círculo hermenêutico", um modelo compreensivointerpretativo que está além de um fundamentar, mas sim compreender um modo-de-ser e uma facticidade (STRECK, 2016a, p. 05).

O sujeito solipsista é aquele que interpreta o mundo - e os entes no interior-do-mundo - e assim o compreende, ou seja, ele se coloca fora do mundo interpretado, como um dado pronto e superior, assujeitando aquilo que por ele é tocado. O problema disso é que lerá o Direito e as instituições vinculadas ao Estado a partir de seu ego, "diz o mundo a partir de sua linguagem privada", bem como pode-se considerar que "o sujeito moderno, no qual o esquema sujeito/objeto está assentado são o cerne do autoritarismo." (STRECK, 2017b, p. 67). Pensase na fenomenologia, na hermenêutica filosófica, julgando-a como a alternativa epistemológica, teórica e, consequentemente, crítica mais compatível para a análise contemporânea, especificamente assentada sobre o neoconstitucionalismo brasileiro, que se inaugura através da carta constitucional de 1988, na qual fica estabelecido o Estado Democrático de Direito (STRECK, 2014, p. 68). É preciso mencionar que um dos grandes problemas do neoconstitucionalismo foi manter em certa medida um Direito "pós-Auschwitz" (STRECK, 2017b, p. 147) que ainda se utilizava da matriz de racionalidade baseada no solipsismo, o que resultou nos problemas de discricionariedade, bem como nos desencontros paradigmáticos 
entre o texto constitucional e as instituições jurídicas do Estado, assim como seus próprios operadores e aplicadores, que ainda se encontram nas amarras da modernidade.

No que se refere à hermenêutica filosófica, a base fenomenológica utilizada no presente artigo partirá de Heidegger e aqueles pensadores posteriores que em boa medida se influenciaram de seu pensamento, como Gadamer, Ernildo Stein, Lenio Streck, desenvolvendo mais precisamente uma hermenêutica aplicada para além da questão existencial. Dois pontos preliminares são relevantes, o primeiro é que o texto de lei - a própria constituição -, bem como o Estado e seu arcabouço constituinte, são considerados fenômenos e, como se verá, entre a lei pura e a norma há a chama diferença ontológica (STRECK, 2017b, p. 49). O segundo ponto é que a interpretação não é condição de possibilidade para a compreensão, mas precisamente o contrário, ou seja, a compreensão prévia nos logra determinada interpretação do fenômeno vivenciado que, assim, será novamente compreendido, o que se denomina fusão de horizontes. Fica de certa forma cristalino que se constrói uma espécie de círculo hermenêutico - será abordado a posteriori - que vincula uma tradição existencial ao fenômeno e/ou ente particular interpretado, vale constar que este não é um círculo vicioso, isto é, um mecanismo objetificante, uma mera técnica procedimental, o que nos remeteria, primeiramente, à hermenêutica clássica/tradicional (GADAMER, 2018, p. 355), bem como às correntes hermenêuticas não substancialistas, mas sim procedimentalistas (STRECK, 2016b, p. 120), como a de Habermas.

Um dos fatores mais relevantes para compreender o âmbito e o impacto da deslegitimação do discurso jurídico-penal é a tendência neoconstitucional de proteção às minorias e grupos vulneráveis que, para além disso, proporcionou o desenvolvimento plural da sociedade e dos sujeitos. Algo que foge do ideário moderno maniqueísta, já muito criticado e ultrapassado, pois "expõe a possibilidade e a necessidade de os indivíduos aspirarem não a um reduzido grupo de valores ou princípios (...) mas a um rol axiológico e principiológico variado" (STRECK, 2017a, p. 02). O problema decorrente é que o sistema penal, como fora constituído historicamente, no caso principalmente da realidade latino-americana, e como está posto hoje, não se comunica adequadamente com este pressuposto pluralista e garantista do neoconstitucionalismo. Isto é, ele continua reproduzindo um discurso colonialista, perverso e que, mais do que nunca, tornou-se deslegitimado frente à esta carta constitucional.

É a partir disso que se distinguirá os penalistas liberais e comunitaristas. Enquanto os primeiros defendem matrizes indivualistas-iluministas-clássicas, os segundos buscam consolidar os princípios neoconstitucionais e a defesa de caráter coletivo (STRECK, 2017a, p. 06). É neste sentido que Streck irá desenvolver e sustentar a ideia do garantismo positivo, indo 
além do garantismo clássico (negativo) - que defende, em última análise, apenas um enxugamento do sistema punitivo (STRECK, 2017a, p. 19). Pelo neoconstitucionalismo abarcar uma gama maior de valores sócio-individuais pode-se deparar com o problema do simples reducionismo penal, portanto é preciso compreender que a Constituição determina tanto uma proteção dos cidadãos frente ao Estado, como uma proteção dos cidadãos através do Estado. Isso impõe uma nova racionalidade e dinâmica de poder do sistema punitivo, que para além do punir deve também promover a eficácia dos direitos e valores protegidos em seu âmbito, mesmo que seja em ultima ratio.

Se antes o Estado e os seus instrumentos legais-institucionais tinham tarefa de proteger apenas os direitos liberais de índole individual contra a "maldade" (sic) do Estado (absenteísta), hoje esse Estado - que passou por profundas transformações - deve preocuparse com essas novas dimensões. É por isso que Baptista Machado e Baratta vão chamar a atenção para o fato de que a tarefa deste novo Estado deve dar resposta para as necessidades de segurança de todos os direitos, incluindo-se nesse rol tambem os prestacionais por parte do Estado (direitos econômicos, sociais e culturais) e não somente daquela parte de direitos denominados de prestação de proteção em particular contra agressões provenientes de comportamentos delitivos de determinadas pessoas. (STRECK, 2017a, p. 26)

É com essa realidade constitucional que o modelo teórico de Zaffaroni, acima trabalhado, ganha grande corroboração para se efetivar, para legitimar uma crítica, desconstruir o sistema posto e todo o estado-de-coisas perverso, reconstruindo a partir de uma nova lógica harmônica constitucionalmente e com maior capacidade de sólida concretização, pois é preciso considerar tratar-se de processo paulatino e não súbito. Isto é, a utilização de um modelo teórico mínimo que norteie um novo sistema punitivo é o primeiro, e mais importante, passo para uma redução eficaz da criminalidade e da própria corrupção sistêmica do Estado e sociedade. O problema criminal não se inicia nas malhas penais, mas deriva de um problema social sistêmico que afeta inúmeras instituições, como a escola. O discurso punitivo perverso produzirá uma verticalização e reprodução destes conflitos. Assim, os problemas não serão resolvidos através da instância estatal de poder mais violenta, ou seja, o sistema penal em seu modelo de punitivismo clássico. Adequar-se ao neoconstitucionalismo é fundamental e o primeiro passo para consolidar um modelo teórico como o de Zaffaroni. 


\section{CONSIDERAÇÕES FINAIS}

Parte-se do pressuposto de que o modelo punitivo de racionalidade predominante em nossa região, assim como em outros países como o Estado Unidos, ou seja, o maximalismo do sistema penal como uma alternativa ao combate da criminalidade não é funcional, sendo incapaz de reduzir os índices delituosos dos países, ao contrário, promove um fomento da violência sistêmica. Neste sentido a importação da política de Tolerância Zero permite demonstrar a ideia de Zaffaroni de neocolonialismo, isto é, a implementação de ideologias sui generis, desde estrutura familiar até políticas de segurança pública baseadas, refletidas, copiadas, dos países centrais do globo, que demonstram desconexão com a realidade em que foram implementadas e, portanto, uma crise no sentido preciso de distanciamento entre racionaldidade-discurso-prática.

Dados do INFOPEN e dos custos econômicos da criminalidade ${ }^{11}$ permitem cristalizar a ineficiência do sistema punitivo vigente; o aumento das taxas de aprisionamento, do número de presos nas penitenciarias, não implica uma redução do índice de criminalidade, ao contrário, ao longo das décadas ficou demonstrado um aumento significativo dos delitos. A realidade econômica do sistema vigente demonstra os altos gastos para manter um punitivismo maximalista e que tende a crescer. Vale ressaltar que este âmbito não proporciona ganhos econômicos, não foi pensado para isso e nem pode, assim, ser utilizado. Contudo, os gastos são preocupantes tendo em vista que reproduz e sustenta um modelo falido.

Propõe-se, então, um caminho diverso do sustentado pelo maximalismo. A alternativa de Hulsman, isto é, o seu modelo Abolicionista é um arcabouço teórico fundamental tanto para corroborar a crítica da deslegitimidade do discurso jurídico-penal, como propor novas estruturas de punição. Importante destacar que, apesar de inexistir nesse modelo o sistema penal em si, a punição ainda permanece e é aplicada em outras instâncias jurídicas de controle social - âmbitos administrativos, por exemplo. Contudo, é um caminho que possui suas problemáticas e limitações, principalmente por não se adequar à realidade brasileira. Implica uma completa mudança no sistema legislativo, judicial e executivo, mas, além disso, um comprometimento social significativo, isto é, uma sociedade bem organizada, orientada e politicamente ativa.

11 Os dados do INFOPEN (sistema de informações estatísticas sobre o sistema prisional brasileiro) podem ser encontrados no seguinte endereço eletrônico: http://depen.gov.br/DEPEN/depen/sisdepen/infopen. Os dados referentes ao custo econômico entorno do sistema criminal nacional podem ser acessados pela conjuntura $n^{\circ} 04$ de 2018 do relatório Custos Econômicos da Criminalidade no Brasil, disponível em: https://download.uol.com.br/noticias/2018/relatorio/custos-economicos-da-criminalidade-no-brasil-06-2018.pdf 
O equilíbrio proposto são as alternativas minimalista de punição, especificamente a de Zaffaroni. Como visto, desenvolve-se toda uma teoria focada na realidade das regiões marginais, da América-latina, incluindo o Brasil. Ela demonstra como, historicamente, o colonialismo e o neocolonialismo impuseram ideologias, valores, modelos teóricos e organizacionais - como a Tolerância Zero - como uma alternativa viável para países com desenvolvimento, culturas e valores completamente diversos. Como Zaffaroni diz, há um grande sincretismo cultural que constitui toda nossa região marginal. Isso permite primeiramente compreender como essas localidades ainda sofrem com ideais ultrapassados, e como as instituições do sistema penal atuam a partir da ideia de um inimigo, uma hostilidade fomentadora de conflitos sociais; por outro lado, permite um resgate significativo da realidade, da facticidade, do mundo ôntico, quebrando em boa parte o vínculo com a região central do globo e construindo um sistema punitivo em harmonia com a realidade local.

Este é o ponto relevante para o telos do trabalho, uma vez que o neoconstitucionalismo implica uma nova e necessária forma de ler a carta constitucional. Trata-se, em outros termos, de vincular todo o ordenamento jurídico infraconstitucional ao constitucionalismo contemporâneo e compreender a realidade não a partir de um esquema solipsista de SujeitoObjeto, uma vez que, na verdade, este esquema nos afasta da realidade e provoca problemas significativos quando analisados no âmbito do Estado e do Direito, por exemplo a esquizofrenização do direito penal.

É preciso solidificar a racionalidade de uma hermenêutica filosófica, compreendendo os modos-de-ser-no-mundo. Para isso é preciso, primeiramente, um resgate da facticidade, da mundidade e da tradição, uma vez que constituem o ser e permitem sua abertura; simultaneamente a própria compreensão do ser das coisas, por exemplo, é preciso saber o que é a pena ou determinado delito, a partir do que estes entes são e/ou devem-ser, se propõe a ser. Por fim, o modelo teórico construído por Zaffaroni proporciona este tipo de leitura, por resgatar não apenas o mundo ôntico, mas também o ontológico. Contudo, é apenas o primeiro passo, trata-se de um repensar complexo no qual o neoconstitucionalismo deve servir como norte, assim como mantendo uma ideia multi/interdisciplinar com diversos outros saberes, como a filosofia. Só assim será possível uma compreensão adequada de uma realidade mais volátil, pluralista e diversificada que o mundo contemporâneo impõe naturalmente. 


\section{REFERÊNCIAS}

BARATTA, A. Criminologia crítica e crítica do direito penal. $6^{\mathrm{a}}$ ed. Rio de Janeiro: Revan. 2011;

BACILA, Carlos Roberto. Criminologia e Estigmas: Um estudo sobre os preconceitos. $4^{\mathrm{a}}$ ed. São Paulo: Atlas. 2015;

BAUMAN, Zygmunt. Globalização: As consequências humanas. Rio de Janeiro: Zahar. 1999;

BONAVIDES, Paulo. Curso de direito constitucional. $28^{\mathrm{a}}$ ed. São Paulo: Editora Malheiros. 2013;

BECCARIA, Cesare. Dos delitos e das penas. $2^{\mathrm{a}}$ ed. São Paulo: Editora Revista dos Tribunais. 1997;

BECK, Ulrich. Sociedade de Risco: Rumo a uma outra modernidade. $1^{\text {a }}$ ed. São Paulo: Editora 34. 2010;

BELLI, Benoni. Tolerância Zero e Democracia. São Paulo: Perspectiva. 2004;

CIRINO, Juarez. Criminologia Critica e a Reforma na Legislação Penal. Florianópolis. 2005;

CIRINO, Juarez. A Criminologia Radical. $2^{\mathrm{a}}$ ed. Rio de Janeiro: Lumem Juris. 2006;

CIRINO, Juarez. Os discursos sobre crime e criminalidade. 2012. Disponível em: http://icpc.org.br/wpcontent/uploads/2012/05/os_discursos_sobre_crime_e_criminalidade.pdf

CIRINO, Juarez. Privatizações dos Presídios; Curitiba: ICPC, 2013;

FERRAJOLI, Luigi: Direito e Razão: A Teoria do Garantismo Penal. $3^{\mathrm{a}}$ ed. São Paulo: Revista dos Tribunais. 2002;

FOUCAULT, Michel. Vigiar e punir. 42a ed. São Paulo: Editora Vozes. 2014a;

FOUCAULT, Michel. Microfísica do Poder. $28^{\circ}$ ed. São Paulo Record. 2014b;

FOUCAULT, Michel. Em defesa da sociedade. $3^{\text {a }}$ reimp. São Paulo: Ed. WMF Martins Fontes. 2018 ;

GADAMER, Hans-Georg. Verdade e Método I: Traços fundamentais de uma hermenêutica filosófica. $15^{\mathrm{a} e d}$. Petrópolis: Ed. Vozes. 2018;

GIDDENS, Anthony. Mundo em Descontrole. $3^{\mathrm{a}}$ ed. São Paulo: Record. 2003;

HEIDEGGER, Martin. Ser e Tempo. $1^{\text {a }}$ reim. Campinas: Ed. UNICAMP. 2014; 
HULSMAN, Louk. Das penas perdidas: O sistema penal em questão. $1^{\mathrm{a}}$ ed. Rio de Janeiro: Editora LUAM. 1993;

PEIRANO, Mariza. Etnocentrismo às avessas: o conceito de "sociedade complexa". Rio de Janeiro: Revista de Ciências Sociais. Vol. 26, n 1. 1983;

STRECK, Lenio Luiz. Ciência Política e Teoria do Estado. $8^{\circ}$ ed. Porto Alegre: Livraria do Advogado. 2014;

STRECK. Lenio. Hermenêutica, Neoconstitucionalismo e o problema da discricionariedade dos juízes. Revista de Direito e Liberdade, v. 18, p. 221-245, 2016a;

STRECK. Lenio. Verdade e Consenso. 6a ed. São Paulo: Saraiva. $2016 \mathrm{~b}$.

STRECK. Lenio. A Dupla Face do Princípio da Proporcionalidade e o cabimento de Mandado de Segurança em matéria criminal: Superando o ideário liberal-individualista-clássico. Brasília: Revista do Ministério Público. № 53. 2017a;

STRECK, Lenio Luiz. Dicionário de Hermenêutica. Belo Horizonte: Casa do Direito. 2017b;

SILVA FILHO, Edson Vieira. O direito penal e suas faces. São Paulo: Lexia. 2013;

SILVA FILHO, Edson Vieira; KALlÁS FILHO, Elias; E. Nós Modernos: A crise da efetividade do constitucionalismo contemporâneo à brasileira. In: SIMIONI. L. R. Constitucionalismo e Democracia: Reflexões do Programa de Pós-Graduação em Direito da FDSM. Editora Max Limonad. 2017;

WACQUANT, Loic. Prisões da Miséria. 1ª ed. São Paulo: ZAHAR. 2001;

ZAFFARONI, Raúl. Direito Penal Brasileiro - I. 4ª ed. Rio de Janeiro: Revan. 2011;

ZAFFARONI, Raúl. La Cuestión Criminal. Argentina: Planeta. 2012;

ZAFFARONI, Raúl. O Inimigo no Direito Penal. $6^{\text {a }}$ ed. Rio de Janeiro: Revan. 2014;

ZAFFARONI, Raúl. Em Busca das Penas Perdidas. 5ª ed. Rio de Janeiro: Revan. 2017;

Trabalho recebido em 05 de julho de 2020

Aceito em 21 de julho de 2021 